\title{
Drying Characteristics of Two Improved Parboiled Rice Varieties
}

\author{
Amina I. Maijalo ${ }^{1}$, Paul Y. Idakwo ${ }^{1 *}$, Ndubisi A. Aviara ${ }^{2}$, Mamudu H. Badau ${ }^{1}$ \\ ${ }^{1}$ Department of Food Science and Technology, Faculty of Engineering, University of Maiduguri, Nigeria \\ ${ }^{2}$ Department of Agricultural and Environmental Resources Engineering, University of Maiduguri, Nigeria
}

DOI: $10.36348 /$ sjet.2020.v05i12.002

| Received: 26.11.2020 | Accepted: 08.12.2020 | Published: 13.12.2020

*Corresponding author: Paul Y. Idakwo

\section{Abstract}

In this study, drying characteristics of two improved parboiled varieties of rice (FARO 44 and FARO 52) at air temperatures of $36^{\circ} \mathrm{C}, 45^{\circ} \mathrm{C}$ and $50^{\circ} \mathrm{C}$ were investigated. The drying data were fitted to seven thin layer drying models, namely, Agbashlo et al., Henderson and Pabis, Logarithmic, Newton, Two Term, Verma et al., and Wang and Singh. The models performances were evaluated by comparing the coefficient of determination $\left(\mathrm{R}^{2}\right)$, standard error (SE) and relationship between the experimental and predicted moisture ratios through nonlinear regression analysis. The main factor controlling the drying rate was temperature and falling rate period characterized the entire drying process. The moisture content of the parboiled rice samples was found to be in the range of $26.33-27.57 \%\left(\mathrm{w}_{\mathrm{b}}\right)$ which reduced to 8.87 $9.98 \%\left(\mathrm{w}_{\mathrm{b}}\right)$ for FARO 44 and $29.37-30.27 \%\left(\mathrm{w}_{\mathrm{b}}\right)$ which reduced to $14.33-14.98 \%\left(\mathrm{w}_{\mathrm{b}}\right)$ for FARO 52 after drying for various temperatures of $36^{\circ} \mathrm{C}, 45^{\circ} \mathrm{C}$ and $50^{\circ} \mathrm{C}$ for eight hours. The $\mathrm{R}^{2}$ and $\mathrm{SE}$ varied between $0.9953-0.9997,0.9917-$ $0.9998,0.9991-0.9999$ and $0.9907-0.9994,0.9986-1.00000 .9300-1.0000$ for FARO 44 and FARO 52 respectively for the seven models. The three best models at $36^{\circ} \mathrm{C}$ for FARO 44 was the Logarithmic followed by Modified Henderson, Pabis and Newton. At $45^{\circ} \mathrm{C}$, the Two term model was the best followed by Verma et al., Modified Henderson and Pabis. While for FARO 52 drying behaviour at each drying temperature of $36^{\circ} \mathrm{C}$, the best model was the Two term followed by Wang and Singh and Logarithmic. The Two term model was the best model at $50^{\circ} \mathrm{C}$. The Two term drying models satisfactorily described the drying behaviour which produced randomized residual plots with highest $\mathrm{R}^{2}$ and lowest standard error of estimates and gave best fitting curves.

Keywords: Drying models, Parboiling, Mathematical modeling, Drying curves, Rice, FARO.

Copyright (C) 2020 The Author(s): This is an open-access article distributed under the terms of the Creative Commons Attribution 4.0 International License (CC BY-NC 4.0) which permits unrestricted use, distribution, and reproduction in any medium for non-commercial use provided the original author and source are credited.

\section{INTRODUCTION}

Rice (Oryza sativa L.) is one of the leading crops of the world. The world rice production is only second to that of wheat and most rice is produced in Asia. The annual production of paddy rice was estimated to be 606 million tonnes mostly in developing countries [1]. Rice is clearly a very important food crop; FAO's first forecast of world paddy production in 2018 saw global output staging a 10.3 million tonnes annual expansion to a new high level of 769.9 million tonnes (510.6 million tonnes, milled basis) [2].

Paddy that is subjected to hydrothermal treatment prior to milling is defined as parboiled rice. Parboiling is practiced in many parts of the world such as Asia, Europe, Africa and America [3, 4]. Traditional parboiling involves soaking the paddy in water, followed by steaming and drying [5]. In Asian countries the use of brown rice and parboiled rice product is rapidly increasing, especially in the preparation of health food and green organic products. The preservation and stability of the main characteristics of food such as taste and crispness during storage often requires control of their moisture content. Several preservation processes have been developed in order to extent the shelf-life of food stuff by lowering the availability of water to micro-organism and inhibiting some chemical reactions. While moisture content is an important criterion to judge food quality [6], water activity is an essential additional parameter to describe water availability and moisture in foods.

The adoption of improved rice varieties including FARO 44 and FARO 52 by rice farmers in Nigeria and good agronomic practices have significantly improved rice production. The benefits of the increase can only translate to better income and livelihood if the rough rice is properly processed or stored under favourable conditions until required for marketing or processing. The two rice varieties in this study are the major rice varieties currently being cultivated in Nigeria under rain-fed or irrigated lowland ecologies and are also the most preferred by millers in Nigeria. Currently there is no data on its drying 
behavior. Since rice contain approximately $80 \%$ carbohydrates and between 10 to $14 \%$ moisture and the required optimum moisture for rice milling is between 12 and $14 \%$, drying parboiled rice to the required moisture level and understanding the drying behavior will greatly improve its processing and head rice recovery. It will also present better direction for large scale drying and storage. In the recent time because of the demand for parboiled rice there is no more strict line of distinction. The quality of parboiled rice during storage primarily depends on water activity which is constituent on the relative humidity and temperature of storage. High moisture content would increase the incidence of microorganisms that cause undesirable fermentation and toxin contamination. For proper milling, drying of steamed parboiled paddy is very important. Therefore the main objectives of the present study were to determine the drying characteristics of two common improved rice varieties; FARO 44 and FARO 52.

\section{MATERIALS AND METHODS \\ Materials and Preparation}

Two different improved rice varieties (FARO 44 and FARO 52) were obtained from the Rice Research Programs of the National Cereals Research Institute (NCRI), Badeggi, Niger State, Nigeria, from the 2015 rain-fed cropping season. All samples were stored in airtight plastic containers and kept under ambient temperature $\left(30 \pm 2^{\circ} \mathrm{C}\right)$ throughout the duration of work. The rice samples were parboiled following the procedure described by Ihekoronye [7]. The initial moisture was determined using Infrared Moisture Analyzer.

\section{Machine Description and Drying procedure}

The dryer consists of four major functioning units (as shown in Figures 1 and 2 below), which are the blower (air inlet unit), heating chamber, diverging unit and the drying chamber. The feed was permitted to arrive at the impeller eye of the blower which turns the flow centrifugally outwards through the blades to the heating chamber thereafter the heated air was diverted into the hot air ducts conveying the air to the drying chamber where the drying process took place.

The diverging unit made it possible for the blower to deliver air to the electrically powered heating element and to the dryer chamber via the configuration of the conveying air inlet ducts. There is moisture exit at the center of the door situated at the front of the drying chamber; the moisture exit (chimney) is directed upwards, so as to allow the vapour to escapes in order to prevent condensation process. The exploded view of the dryer depicts all the aforementioned.

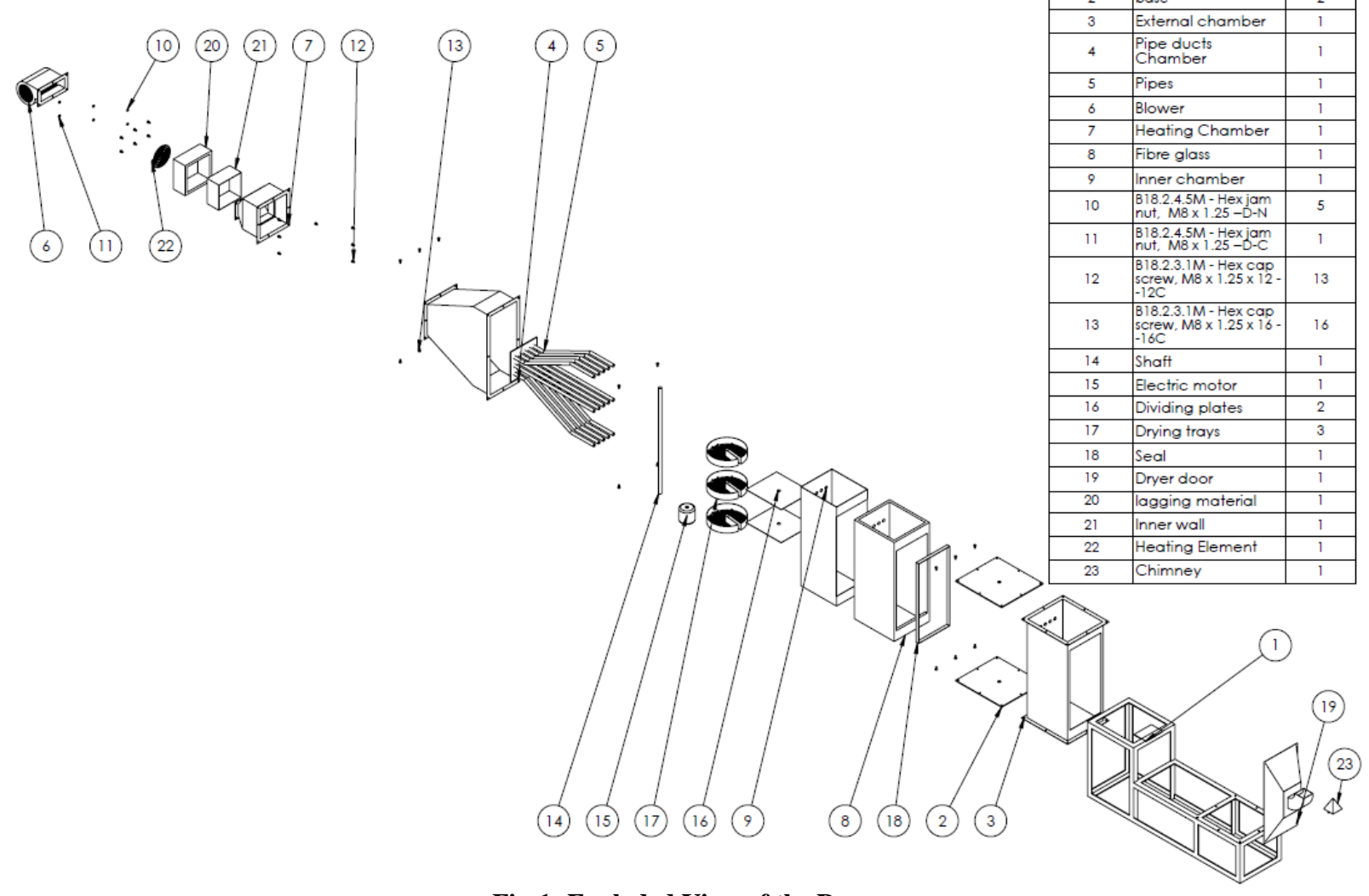

Fig-1: Exploded View of the Dryer 


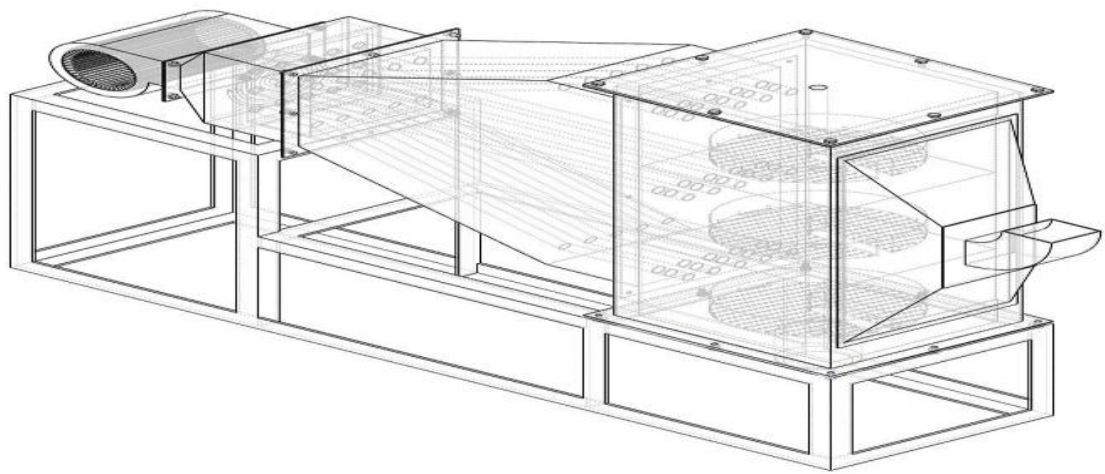

Fig-2: Isometric Projections of the Dryer

\section{Drying procedure}

The procedure employed by Aviara and Igbeka [8] was adopted with modifications to suit the laboratory and experimental conditions. The initial moisture content of the rice varieties was noted. Prior to each experiment, the dryer was allowed to run empty at selected temperature and air velocity until the drying chamber attained thermal equilibrium.

Triplicate sample of known weight was placed in the drying trays and placed in the drying chamber with fan running. A change in the sample weight was monitored throughout the experiment by weighing periodically with the help of electric balance. The weighing of samples was carried out every $10 \mathrm{~min}$. This weighing was continued until three consecutive readings produced identical values. The test was terminated, the time taken was recorded and equilibrium with the drying environment was assumed to have been reached.

\section{Data Analysis}

Drying time, equilibrium moisture content, and drying rate phases

The moisture content at a given time and the drying temperature were obtained using the equation derived by Kajuna et al, [9] stated as follows:

$$
M_{i}=\frac{M_{i} m_{i}-W_{l}}{m_{i}-W_{i}}
$$

Where $\mathrm{M}_{\mathrm{t}}$ is the moisture content (\%) at a given time $t, M_{i}$ is the initial moisture content of the rice, $(\%), \mathrm{m}_{\mathrm{i}}$ is the initial mass of the wet rice, $(\mathrm{g})$ and $\mathrm{W}_{\mathrm{i}}$ is the mass loss $(\mathrm{g})$ at time $\mathrm{t}$.

\section{Drying characteristics of Rice varieties}

The weight of the samples, the drying time and the weight losses were recorded and the values obtained were used for plotting of the graphs, which included;

1. The plot of moisture content against time

2. The plot of drying rate against time and

3. The plot of drying rate against moisture content.

\section{Mathematical modeling of drying curve}

These models have been widely used to model drying of different agricultural products [10-14]. In these models the terms of moisture ratio, MR, and the drying rate $\mathrm{DR}$, of the rice during drying experiment were calculated by the equations below.

$$
M R=\frac{M-M_{e}}{M_{i}-M_{e}}
$$

MR is the moisture ratio, which is a dimensionless parameter that normalizes the drying curves, $\mathrm{M}$ is the moisture content at a given time $(\%$, $\mathrm{db}), \mathrm{M}_{\mathrm{i}}$ is the initial moisture content of the sample (\%, $\mathrm{db}), \mathrm{M}_{\mathrm{e}}$ is the equilibrium moisture content $(\%, \mathrm{db})$

Drying Rate: $(D R)=\frac{\left(M_{t}+d_{t}\right)-M_{t}}{d_{t}}$

DR ( $\left.g_{\text {water }} g_{d m}^{-1} \min ^{-1}\right)$ and $d t$ (min) are the drying rate and the period between two consecutive measurements.

Drying models (Table-1) were fitted to the drying data of rice samples at different temperatures using the non-linear regression procedure made possible by STATISTIX 9 statistical analysis software (Analytical Software Inc.). The observed and predicted moisture ratios were compared and statistically analyzed to determine the best-fit equation. The goodness of fit of each model was evaluated using the coefficient of determination and standard error of estimate, and residual plots.

The regression analysis was performed using statistical computer program STATISTICS 9. The correlation coefficient $\left(\mathrm{R}^{2}\right)$ was the primary criterion for the selection of best equation to describe the drying curve equation. In addition to $\mathrm{R}^{2}$, The standard error of estimate (SEE) was used to determine the goodness of fit. The higher the value of $\mathrm{R}^{2}$ and lower the values of $\mathrm{SSE}$, the better the goodness of fit $[11,15,10,16]$. The measured and simulated moisture contents were compared and statistically analyzed for determining the best fit equation. The standard error of estimate (SEE) indicated the fitting ability of a model to a data set. The 
Amina I. Maijalo et al; Saudi J Eng Technol, Dec, 2020; 5(12): 491-500

smaller the SEE value, the better the fitting ability of an equation. For the same data set, the equation giving the smallest SEE value represented the best fitting ability $[17,18]$. The standard error of estimate (SEE) is expressed as:

$\mathrm{SEE}=\sqrt{\frac{\sum_{\mathrm{i}=\mathrm{i}}^{\mathrm{m}}\left(\mathrm{m}_{\mathrm{t}}-\mathrm{m}_{\mathrm{s}}\right)^{2}}{\mathrm{~m}}}$

$\mathrm{R}^{2}=\left(1-\frac{\sum\left(\mathrm{MR}_{\mathrm{obs}}-\mathrm{MR}_{\mathrm{pred}}\right)^{2}}{\sum\left(\mathrm{MR}_{\mathrm{obs}}-\mathrm{MR}_{\text {mean }}\right)^{2}}\right)$
Where $M R_{\text {obs }}$ and $M R_{\text {pred }}$ are observed and predicted moisture ratio values, respectively, $\mathrm{N}$ is the number of observation in each set and $\mathrm{MR}_{\text {mean }}$ is the mean of the observed moisture ratio values.

Residual plots were used as the criterion to evaluate the adequacy of the models. If the residual plots presented a clear pattern, the model was considered inadequate. If the residual plots exhibited a randomized distribution, the model was considered adequate for these drying data.

Table-1: Mathematical models applied to the drying curves of the rice varieties

\begin{tabular}{|l|l|c|l|}
\hline S/N & Model Name & Model Equation & References \\
\hline 1. & Aghbashlo et al. & MR $=\exp \left(-\frac{\mathrm{kt}}{1}+\mathrm{ct}\right)$ & {$[19]$} \\
\hline 2. & Henderson and Pabis & $\mathrm{MR}=\mathrm{aexp}(-\mathrm{kt})$ & {$[20]$} \\
\hline 3. & Newton & $\mathrm{MR}=\exp (-\mathrm{kt})$ & {$[21]$} \\
\hline 4. & Logarithmic & $\mathrm{MR}=\mathrm{a} \exp (-\mathrm{kt})+\mathrm{c}$ & {$[22]$} \\
\hline 5. & Two term model & $\mathrm{MR}=\mathrm{a} \exp \left(-\mathrm{k}_{0} \mathrm{t}\right)+\mathrm{bexp}\left(-\mathrm{k}_{1} \mathrm{t}\right)$ & {$[23]$} \\
\hline 6. & Midilli Kucuk & $\mathrm{MR}=\mathrm{aexp}\left(-\mathrm{kt}^{\mathrm{n}}\right)+\mathrm{bt}$ & {$[24]$} \\
\hline 7. & Wang and Singh & $\mathrm{MR}=1+\mathrm{at}+\mathrm{bt}^{2}$ & {$[25]$} \\
\hline
\end{tabular}

\section{RESULTS AND DISCUSSION \\ Drying curves}

Parboiled rice samples were dried at $36^{\circ} \mathrm{C}$, $45^{\circ} \mathrm{C}$ and $50^{\circ} \mathrm{C}$ of drying temperatures in order to determine the effect of temperature on drying characteristics of the parboiled rice. The drying curves showing the variation of moisture content with drying time at different temperatures are as presented in Figures 3 and 4 for FARO 44 and FARO 52 rice varieties, respectively. The moisture content of the parboiled rice samples was found to be in the range of $26.33-27.57 \%\left(\mathrm{w}_{\mathrm{b}}\right)$ which reduced to $8.87-9.98 \%\left(\mathrm{w}_{\mathrm{b}}\right)$ for FARO 44 and $29.37-30.27 \%\left(\mathrm{w}_{\mathrm{b}}\right)$ which reduced to $14.33-14.98 \%\left(\mathrm{w}_{\mathrm{b}}\right)$ for FARO 52 after drying for various temperatures of $36^{\circ} \mathrm{C}, 45^{\circ} \mathrm{C}$ and $50^{\circ} \mathrm{C}$ drying for eight hours.

Within the temperature range used, the time to reach the dynamic equilibrium moisture in both varieties reduced with increasing temperature. Therefore, it was observed from the curves that temperature of drying had significant effect on the drying time. Generally, moisture removal from both varieties was steadily until equilibrium moisture content was reached. However, at $45^{\circ} \mathrm{C}$ and $50^{\circ} \mathrm{C}$, the time taken to dry FARO 44 (200 minutes and 265 minutes respectively) are lower than that of FARO 52 (250 minutes and 310 minutes respectively) at the same temperature and this showed that the initial moisture content of FARO 52 was higher than FARO 44. Similarly, the higher the drying rate, described as the amount of water removed per time [15] the shorter the time taken to dry the product (Figures 5 and 6) the thinlayer drying periods of FARO 44 and FARO 52. This drying rate was higher at higher temperatures as evident by the steeper slopes in both varieties (Figures 7 and 8).
The slopes became steeper with increase in temperature indicating increasing drying rate. In all the cases, at the beginning of the drying process, drying rate was higher, but decreased continuously with decreasing moisture content as the drying time progressed. There was no marked constant rate phase as drying in both varieties seemed to start and preceded in the falling rate phase. The result suggests that diffusion is the most likely physical mechanism governing the moisture movement in the rice samples and this agreed with some past studies on drying of various food products especially grains and legumes, the category to which rice belongs $[26,15,8]$. Therefore it was observed from the curves that temperature of drying air had significant effect on the drying time. As the drying temperature increased from $36^{\circ} \mathrm{C}$ to $50^{\circ} \mathrm{C}$, there was reduction in drying time. Meanwhile FARO 44 had higher initial drying rate of 0.2 and 0.14 at the temperatures of $50^{\circ} \mathrm{C}$ and $45^{\circ} \mathrm{C}$ but lower drying rate of 0.07 at $50^{\circ} \mathrm{C}$ and FARO 52 had $0.17,0.11$ at $50^{\circ} \mathrm{C}$ and $45^{\circ} \mathrm{C}$ and 0.09 at $50^{\circ} \mathrm{C}$.

These results were consistent with previously published studies of drying millet by Ojediran and Raji [27], banana slices by Abano and Sam [28] and native cassava starch by Aviara and Igbeka [8]. In addition Rice on maturity are hard and have low moisture content hence they are harvested at low moisture content implying very low or no surface and/or capillary water which are responsible for constant rate drying. This is unlike the fruits and vegetables with existence of two drying rate periods namely the constant rate period and the falling rate period as shown by [29] in artificial drying of bell pepper. 
Amina I. Maijalo et al; Saudi J Eng Technol, Dec, 2020; 5(12): 491-500

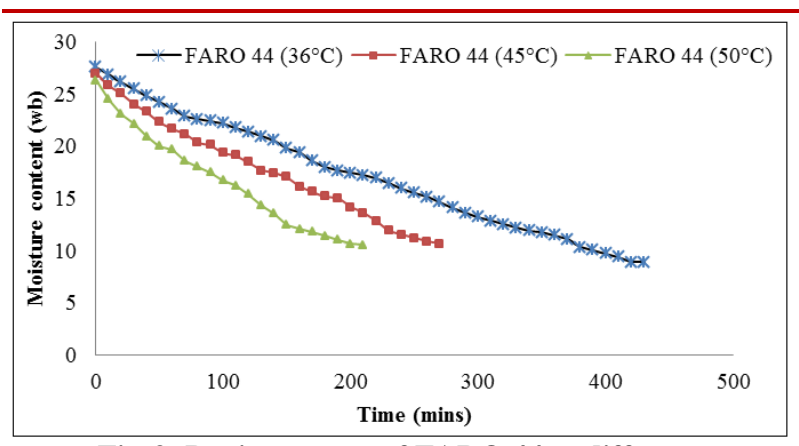

Fig-3: Drying curves of FARO 44 at different temperatures

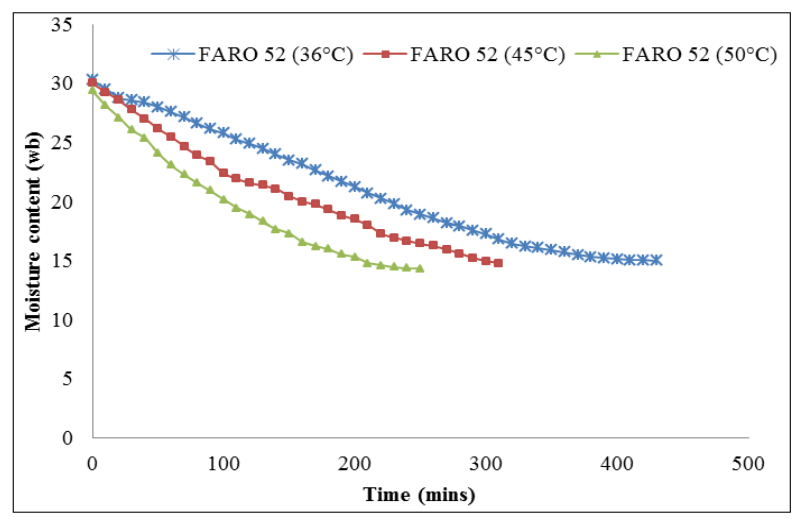

Fig-4: Drying curves of FARO 52 at different temperatures

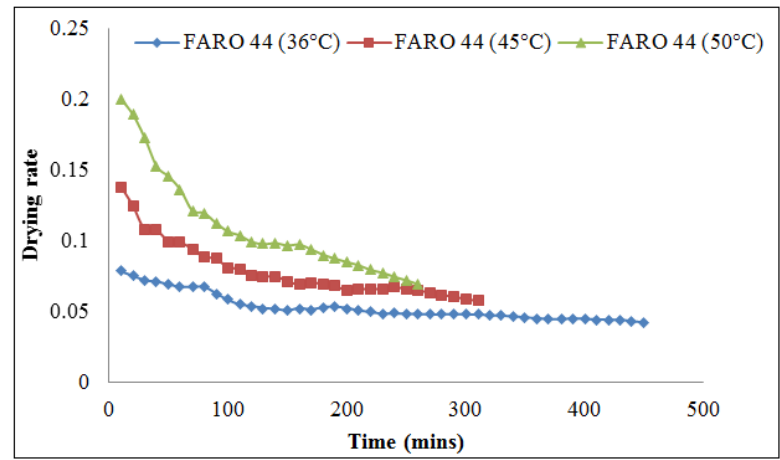

Fig-5: Thin-layer drying periods of FARO 44 at different temperatures

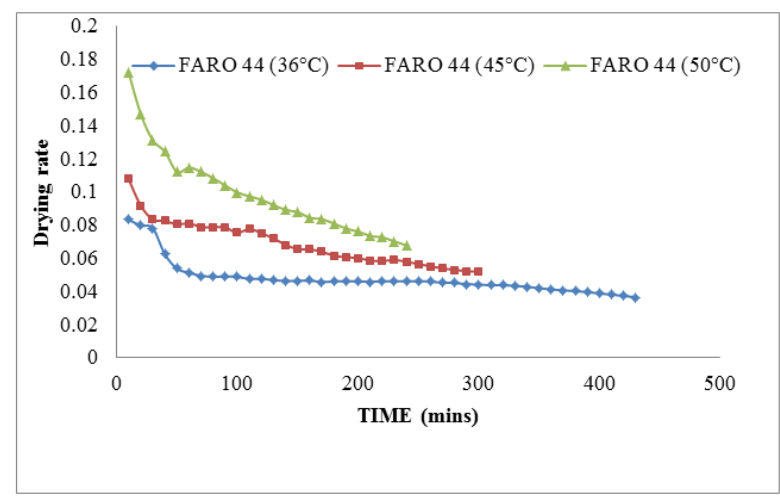

Fig-6: Thin-layer drying period of FARO 52 at different temperatures

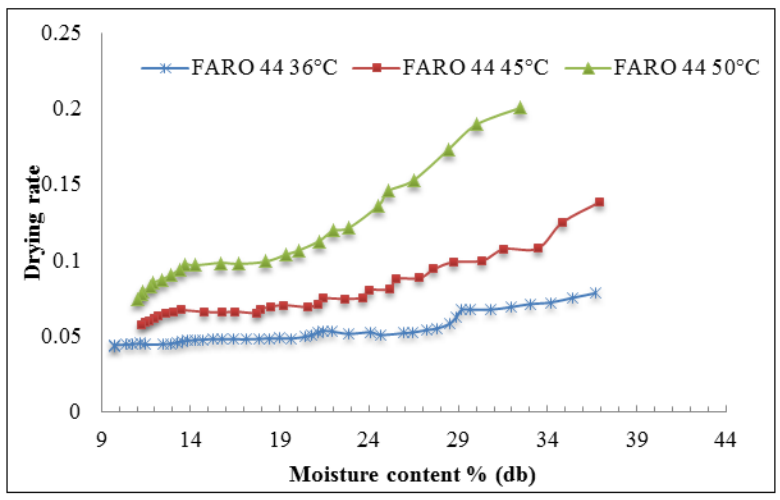

Fig-7: Thin-layer drying rate periods of FARO 44 at different temperatures

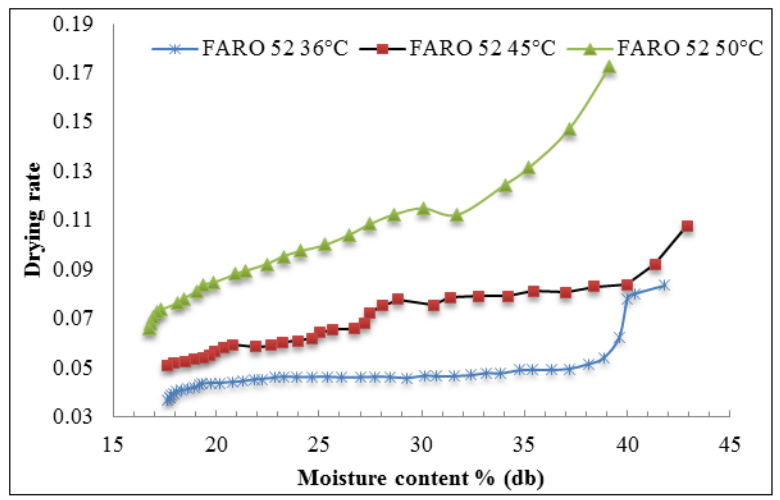

Fig-8: Thin-layer drying periods of FARO 52 at different temperatures

\section{Drying Model Evaluation}

The parameter estimates and comparison criteria for the thin-layer drying models, tested on the rice varieties over a temperature range of $36-50^{\circ} \mathrm{C}$, are presented in Tables 2 and 3. These Tables showed that at $36^{\circ} \mathrm{C}$, all the seven models were acceptable for predicting the drying behaviour of the rice varieties (with randomized residual plots), only three of the seven models evaluated, namely, the Aghbashlo et al., Modified Henderson and Pabis and the Newton models (with patterned residual plots at drying temperatures of $45^{\circ} \mathrm{C}$ and $50^{\circ} \mathrm{C}$ ) were unacceptable for predicting the drying behavior of the rice varieties. However, upon all the models that were acceptable (with randomized residual plots), the Two term model consistently gave better prediction results with the highest value of $R^{2}$ and the lowest standard error of estimate among the models.

The three best models for the FARO 44 and FARO 52 drying behaviour at each drying temperature in the above range are presented in Table 4 . The Table showed that, at $36^{\circ} \mathrm{C}$, the best model for FARO 44 was the Logarithmic followed by Modified Henderson and Pabis and Newton. At $45^{\circ} \mathrm{C}$, the Two term model was the best followed by Verma et al., and Modified Henderson and Pabis. The Two term model was the best model at $50^{\circ} \mathrm{C}$. At each drying temperature, the best model for FARO44 variety was stated as follows: 


$$
\begin{aligned}
& \mathbf{3 6}^{\circ} \mathbf{C}: \mathrm{MR}=1.1447 * \exp \left(-2.30 \times 10^{-3} * \mathrm{t}\right)-0.1671\left(\mathrm{R}^{2}=0.9997\right) \ldots \ldots \ldots \ldots \ldots \ldots \ldots \ldots \ldots \ldots \ldots \ldots \ldots \ldots \ldots \ldots \ldots \ldots \\
& \mathbf{4 5}^{\circ} \mathbf{C}: M R=2.76 \times 10^{-3} \exp \left(7.14 \times 10^{-3} * \mathrm{t}\right)+(0.9770) \exp \left(-4.15 \times 10^{-3} * \mathrm{t}\right)\left(\mathrm{R}^{2}=0.9998\right) \\
& \mathbf{5 0}^{\circ} \mathbf{C}: \mathrm{MR}=0.9618 \exp \left(-5.75 \times 10^{-3} * \mathrm{t}\right)+6.75 \times 10^{-4} * \exp (0.0191 * \mathrm{t})\left(\mathrm{R}^{2}=0.9999\right) \ldots \ldots \ldots \ldots
\end{aligned}
$$

Similarly for FARO 52 drying behaviour at each drying temperature of $36^{\circ} \mathrm{C}$, the best model was the Two term followed by Wang and Singh and Logarithmic.
The above order of performance was repeated at $45^{\circ} \mathrm{C}$, with the Wang and Singh model displacing Verma et al., as the second. The Two term model maintained its position as the best model at $50^{\circ} \mathrm{C}$. At each drying temperature, the Two term model for FARO 52 was stated as follows:

$$
\begin{aligned}
& \mathbf{3 6}^{\circ} \mathbf{C}: M R=1.0063 \exp \left(-2.45 \times 10^{-3} * \mathrm{t}\right)+1.16 \times 10^{-5} * \exp (0.0196 * \mathrm{t})\left(\mathrm{R}^{2}=0.9974\right) \ldots \ldots \\
& \mathbf{4 5}^{\circ} \mathbf{C}: \mathrm{MR}=0.3997 \exp \left(-8.60 \times 10^{-3} * \mathrm{t}\right)+0.6074 * \exp \left(-1.51 \times 10^{-3} * \mathrm{t}\right)\left(\mathrm{R}^{2}=0.9999\right) \\
& \mathbf{5 0}^{\circ} \mathbf{C}: \mathrm{MR}=0.3997 \exp \left(-8.60 \times 10^{-3} * \mathrm{t}\right)+0.6074 * \exp \left(-1.51 \times 10^{-3} * \mathrm{t}\right)\left(\mathrm{R}^{2}=1.0000\right)
\end{aligned}
$$

\begin{tabular}{|c|c|c|c|c|c|c|c|c|c|}
\hline \multirow[t]{2}{*}{ Model } & \multicolumn{6}{|l|}{ Constants } & \multirow[t]{2}{*}{$\mathbf{R}^{2}$} & \multirow[t]{2}{*}{ SE } & \multirow[t]{2}{*}{ Residual } \\
\hline & $\mathbf{A}$ & b & C & $\mathbf{g}$ & $\mathbf{H}$ & $\mathbf{K}$ & & & \\
\hline \multicolumn{10}{|l|}{$36^{\circ} \mathrm{C}$} \\
\hline Aghbashlo et al. & & & 0.9986 & & & 1.0013 & 0.9986 & 0.0142 & Randomized \\
\hline Logarithmic & 1.1447 & & -0.1671 & & & $2.301 \times 10^{-3}$ & 0.9997 & 0.0109 & Randomized \\
\hline $\begin{array}{l}\text { Modified Henderson } \\
\text { and Pabis }\end{array}$ & -0.0248 & & 0.0249 & $3.012 \times 10^{-}$ & 0.7189 & 0.0212 & 0.9996 & 0.0137 & Randomized \\
\hline Newton & & & & & & $3.021 \times 10^{-3}$ & 0.9996 & 0.0140 & Randomized \\
\hline Two term & 0.4972 & & 0.4972 & $2.996 \times 10^{-}$ & & $2.996 \times 10^{-3}$ & 0.9980 & 0.0144 & Randomized \\
\hline Verma et al & 0.9934 & & & 2.0558 & & $2.992 \times 10^{-3}$ & 0.9960 & 0.0142 & Randomized \\
\hline Wang and Singh & $2.696 \times 10^{-3}$ & $1.518 \times 10^{-3}$ & & & & & 0.9953 & 0.0152 & Randomized \\
\hline \multicolumn{10}{|l|}{$45^{\circ} \mathrm{C}$} \\
\hline Aghbashlo et al. & & & 0.9987 & & & 1.0028 & 0.9917 & 0.0196 & Randomized \\
\hline Logarithmic & 0.9198 & & 0.0604 & & & $4.431 \times 10^{-3}$ & 0.9987 & 0.0155 & Randomized \\
\hline $\begin{array}{l}\text { Modified Henderson } \\
\text { and Pabis }\end{array}$ & 0.0350 & & -0.0349 & $3.900 \times 10^{-}$ & $\frac{3.877 \times 10^{-}}{3}$ & 0.6044 & 0.9997 & 0.0157 & Patterned \\
\hline Newton & & & & & & $4.11 \times 10^{-3}$ & 0.9995 & 0.0193 & Randomized \\
\hline Two term & $2.763 \times 10^{-3}$ & & 0.9770 & ${ }_{3}^{4.146 \times 10^{-}}$ & & $\frac{-7.139 \times 10^{-}}{3}$ & 0.9998 & 0.0155 & Randomized \\
\hline Verma et al & 0.9555 & & & 0.0656 & & $3.846 \times 10^{-3}$ & 0.9998 & 0.0147 & Randomized \\
\hline Wang and Singh & $-1.287 \times 10^{-}$ & $\frac{-1.287 \times 10^{-}}{6}$ & & & & & 0.9997 & 0.0731 & Randomized \\
\hline \multicolumn{10}{|l|}{$50^{\circ} \mathrm{C}$} \\
\hline Aghbashlo et al. & 1.0026 & & & & & 1.0082 & 0.9991 & 0.0365 & Patterned \\
\hline Logarithmic & 0.7872 & & 0.1891 & & & $8.049 \times 10^{-3}$ & 0.9998 & 0.0171 & Randomized \\
\hline $\begin{array}{l}\text { Modified Henderson } \\
\text { and Pabis }\end{array}$ & -0.0825 & & 0.0825 & ${ }_{3}^{4.933 \times 10^{-}}$ & 0.5920 & $4.825 \times 10^{-3}$ & 0.9997 & 0.0237 & Randomized \\
\hline Newton & & & & & & $5.615 \times 10^{-3}$ & 0.9993 & 0.0358 & Patterned \\
\hline Two term & 0.9618 & & $6.752 \times 10^{-}$ & -0.0191 & & $5.747 \times 10^{-3}$ & 0.9999 & 0.0153 & Randomized \\
\hline Verma et al & 0.0971 & & & $7.744 \times 10^{-}$ & & $-2.261 \times 10^{-}$ & 0.9998 & 0.0186 & Randomized \\
\hline Wang and Singh & $-5.772 \times 10^{-}$ & $1.214 \times 10^{-4}$ & & & & & 0.9998 & 0.0224 & Randomized \\
\hline
\end{tabular}

Table-2: Drying constants and coefficients of the models for FARO 44 at $36^{\circ} \mathrm{C}, 45^{\circ} \mathrm{C}$ and $50^{\circ} \mathrm{C}$ 
Amina I. Maijalo et al; Saudi J Eng Technol, Dec, 2020; 5(12): 491-500

\begin{tabular}{|c|c|c|c|c|c|c|c|c|c|}
\hline \multicolumn{10}{|c|}{ Table-3: Drying constants and coefficients of the models for FARO 52 at $36^{\circ} \mathrm{C}, 45^{\circ} \mathrm{C}$ and $50^{\circ} \mathrm{C}$} \\
\hline \multirow[t]{2}{*}{ Model } & \multicolumn{6}{|c|}{ Constants } & \multirow[t]{2}{*}{$\mathbf{R}^{2}$} & \multirow[t]{2}{*}{ SE } & \multirow[t]{2}{*}{ Residual } \\
\hline & A & b & c & g & $\mathbf{H}$ & $\mathbf{K}$ & & & \\
\hline \multicolumn{10}{|l|}{$36^{\circ} \mathrm{C}$} \\
\hline Aghbashloet al. & & & 0.9993 & & & 1.0016 & 0.9907 & 0.0184 & Randomized \\
\hline Logarithmic & 0.9026 & & 0.1596 & & & $3.094 \times 10^{-}$ & 0.9994 & 0.0158 & Randomized \\
\hline $\begin{array}{l}\text { Modified } \\
\text { Henderson and } \\
\text { Pabis }\end{array}$ & 1.0072 & & -1.0062 & $2.326 \times 10^{-}$ & 0.0934 & 0.0988 & 0.9994 & 0.0186 & Randomized \\
\hline Newton & & & & & & $2.32 \times 10^{-3}$ & 0.9907 & 0.0182 & Randomized \\
\hline Two term & 1.0063 & & ${ }_{5} .161 \times 10^{-}$ & -0.0196 & & $2.451 \times 10^{-}$ & 0.9974 & $\begin{array}{l}9.900 \times 10^{-} \\
-\end{array}$ & Randomized \\
\hline Vermaet al & 0.9910 & & & 2.2480 & & $2.291 \times 10^{-}$ & 0.9910 & 0.0183 & Randomized \\
\hline $\begin{array}{l}\text { Wang and } \\
\text { Singh }\end{array}$ & $-2.363 \times 10^{-}$ & ${ }_{6}^{2.214 \times 10^{-}}$ & & & & & 0.9981 & 0.0117 & Randomized \\
\hline \multicolumn{10}{|l|}{$45^{\circ} \mathrm{C}$} \\
\hline $\begin{array}{l}\text { Aghbashlo et } \\
\text { al. }\end{array}$ & & & 0.9986 & & & 1.0029 & 0.9986 & 0.0275 & Patterned \\
\hline Logarithmic & 0.7164 & & 0.2852 & & & $5.632 \times 10^{-}$ & 1.0000 & $8.537 \times 10^{-}$ & Randomized \\
\hline $\begin{array}{l}\text { Modified } \\
\text { Henderson and } \\
\text { Pabis }\end{array}$ & 0.3997 & & -0.3926 & $1.514 \times 10^{-}$ & $1.514 \times 10^{-}$ & $\begin{array}{l}8.602 \times 10^{-} \\
\end{array}$ & 1.0000 & ${ }_{3}^{8.457 \times 10^{-}}$ & Randomized \\
\hline Newton & & & & & & $\begin{array}{l}3.209 \times 10^{-} \\
-\end{array}$ & 0.9997 & 0.0271 & Patterned \\
\hline Two term & 0.3997 & & 0.6074 & $1.514 \times 10^{-}$ & & $8.602 \times 10^{-}$ & 0.9999 & $8.315 \times 10^{-}$ & Randomized \\
\hline Verma et al., & 0.4956 & & & $7.084 \times 10^{-}$ & & $1.104 \times 10^{-}$ & 0.9999 & $\begin{array}{l}8.374 \times 10^{-} \\
-\end{array}$ & Randomized \\
\hline $\begin{array}{l}\text { Wang and } \\
\text { Singh }\end{array}$ & $\begin{array}{l}- \\
3.490 \times 10^{-}\end{array}$ & ${ }_{6}^{5.185 \times 10^{-}}$ & & & & & 0.9997 & 0.0132 & Randomized \\
\hline \multicolumn{10}{|l|}{$50^{\circ} \mathrm{C}$} \\
\hline $\begin{array}{l}\text { Aghbashlo et } \\
\text { al., }\end{array}$ & 1.0029 & & & & & 1.0029 & 0.9605 & 0.0372 & Patterned \\
\hline Logarithmic & 0.9729 & & 0.9729 & & & $3.979 \times 10^{-}$ & 0.9987 & 0.0302 & Randomized \\
\hline $\begin{array}{l}\text { Modified } \\
\text { Henderson and } \\
\text { Pabis }\end{array}$ & -0.0686 & & 0.0687 & $\begin{array}{l}3.865 \times 10^{-} \\
3\end{array}$ & 0.9300 & $3.865 \times 10^{-}$ & 0.9300 & 0.0287 & Patterned \\
\hline Newton & & & & & & $\begin{array}{l}4.380 \times 10^{-} \\
3\end{array}$ & 0.9984 & 0.0365 & Patterned \\
\hline Two term & 0.9359 & & 0.0608 & $\begin{array}{l}- \\
4.702 \times 10^{-}\end{array}$ & & $6.093 \times 10^{-}$ & 1.0000 & $\begin{array}{l}4.545 \times 10^{-} \\
3\end{array}$ & Randomized \\
\hline Verma et al & 0.0757 & & & ${ }_{3}^{6.310 \times 10^{-}}$ & & $\begin{array}{l}- \\
4.074 \times 10^{-}\end{array}$ & 0.9997 & $\begin{array}{l}4.554 \times 10^{-} \\
-\end{array}$ & Randomized \\
\hline $\begin{array}{l}\text { Wang and } \\
\text { Singh }\end{array}$ & $\begin{array}{l}- \\
\end{array} .934 \times 10^{-}$ & $1.029 \times 10^{-}$ & & & & & 0.9992 & $9.435 \times 10^{-}$ & Randomized \\
\hline
\end{tabular}


Amina I. Maijalo et al; Saudi J Eng Technol, Dec, 2020; 5(12): 491-500

Table-4: Three best models for expressing the drying characteristics of FARO 44 and FARO 52 rice varieties at different temperatures

\begin{tabular}{|c|c|c|c|c|}
\hline Rice varieties & Temperature $\left({ }^{\circ} \mathrm{C}\right)$ & Model & $\mathbf{R}^{2}$ & SE \\
\hline \multirow[t]{9}{*}{ FARO 44} & \multirow[t]{3}{*}{$36^{\circ} \mathrm{C}$} & Logarithmic & 0.9997 & 0.0109 \\
\hline & & Modified Henderson and Pabis & 0.9996 & 0.0137 \\
\hline & & Newton & 0.9996 & 0.0140 \\
\hline & \multirow[t]{3}{*}{$45^{\circ} \mathrm{C}$} & Two term & 0.9998 & 0.0155 \\
\hline & & Verma et al. & 0.9998 & 0.0157 \\
\hline & & Modified Henderson and Pabis & 0.9997 & 0.0157 \\
\hline & \multirow[t]{3}{*}{$50^{\circ} \mathrm{C}$} & Two term & 0.9999 & 0.0153 \\
\hline & & Logarithmic & 0.9998 & 0.0171 \\
\hline & & Verma et al. & 0.9998 & 0.0186 \\
\hline \multirow[t]{9}{*}{ FARO 52} & \multirow[t]{3}{*}{$36^{\circ} \mathrm{C}$} & Two term & 0.9974 & $9.900 \times 10^{-3}$ \\
\hline & & Wang and Singh & 0.9981 & 0.0117 \\
\hline & & Logarithmic & 0.9994 & 0.0158 \\
\hline & \multirow[t]{3}{*}{$45^{\circ} \mathrm{C}$} & Two term & 0.9999 & $8.315 \times 10^{-3}$ \\
\hline & & Verma et al. & 0.9999 & $8.374 \times 10^{-3}$ \\
\hline & & Logarithmic & 1.0000 & $8.537 \times 10^{-3}$ \\
\hline & \multirow[t]{3}{*}{$50^{\circ} \mathrm{C}$} & Two term & 1.0000 & $4.545 \times 10^{-3}$ \\
\hline & & Verma et al. & 0.9997 & $4.554 \times 10^{-3}$ \\
\hline & & Wang and Singh & 0.9992 & $9.432 \times 10^{-3}$ \\
\hline
\end{tabular}

The drying data obtained in the experiments were converted to dimensionless moisture ratio (MR) and then plotted against time. Figures 9 and 10 showed the variation of the observed and predicted moisture ratio with drying time at different temperatures for FARO 44 and FARO 52 respectively. It was observed that moisture ratio decreased exponentially with time. The final moisture ratio was reached after the periods of 260, 340 and 460 minutes at 36, 45 and $50{ }^{\circ} \mathrm{C}$, respectively. Moisture ratio showed a rapid decline over time in the initial drying period which indicated that during this drying period; both FARO 44 and FARO 52 achieved a constant drying rate. The result was consistent with previously published studies [30]. The difference between moisture ratios increased gradually at the commencement of drying and the time required reaching equilibrium moisture content decreased with increasing temperature. Thus, the effect of temperature on drying rate has been established for rice. Similar results were reported by [ 8 for starch with an initial moisture content of $82 \%(\mathrm{db})$, the drying time and dynamic equilibrium moisture content decreased as the temperature increased. The constant drying rate phase preceded the falling rate phase between $40-55^{\circ} \mathrm{C}$.

Figure 11 and 12 compared the observed data with those predicted with the logarithmic at $36^{\circ} \mathrm{C}$ and Two term model at $45^{\circ} \mathrm{C}$ and $50^{\circ} \mathrm{C}$ for FARO 44 and Two term model at $36^{\circ} \mathrm{C}, 45^{\circ} \mathrm{C}$ and $50^{\circ} \mathrm{C}$ for FARO 52 rice varieties. The prediction using the model showed MR value banded along the straight line with a high $\mathrm{R}^{2}$ value, which showed that the model follows the drying curves and the suitability of these models in describing drying characteristics of the FARO 44 and FARO 52.

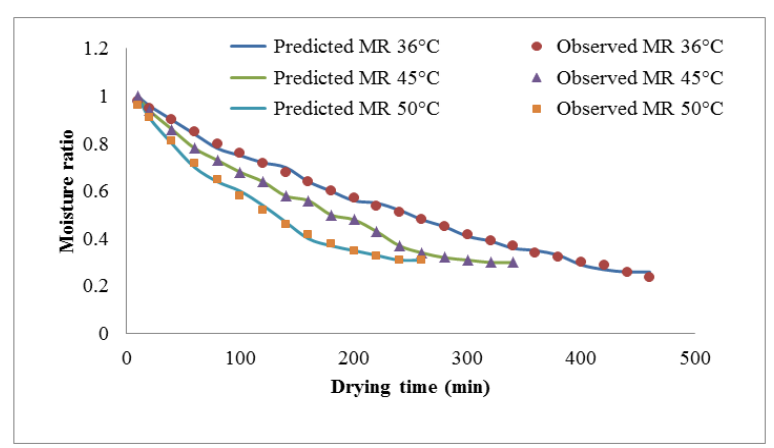

Fig-9: FARO 44 at different temperatures

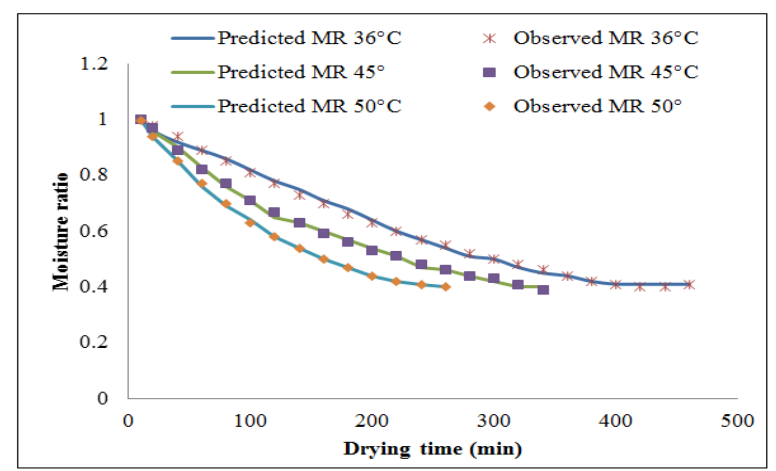

Fig-10: FARO 52 at different temperatures

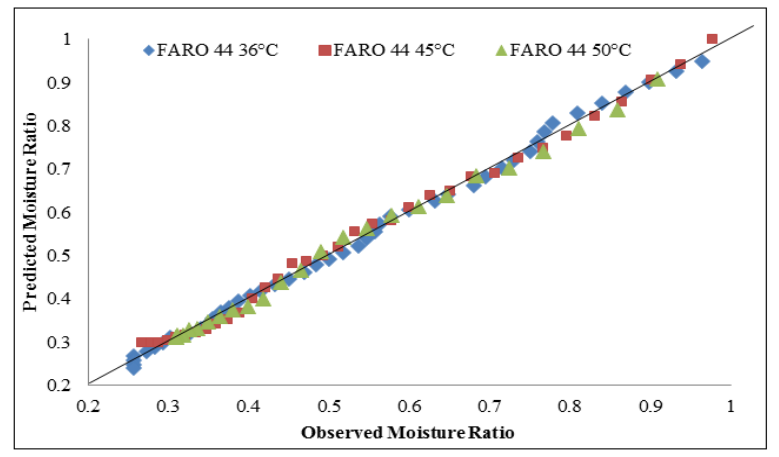

Fig-11: Predicted Moisture Ratio against Observed Moisture Ratio of FARO 44 dried at different temperatures 
Amina I. Maijalo et al; Saudi J Eng Technol, Dec, 2020; 5(12): 491-500

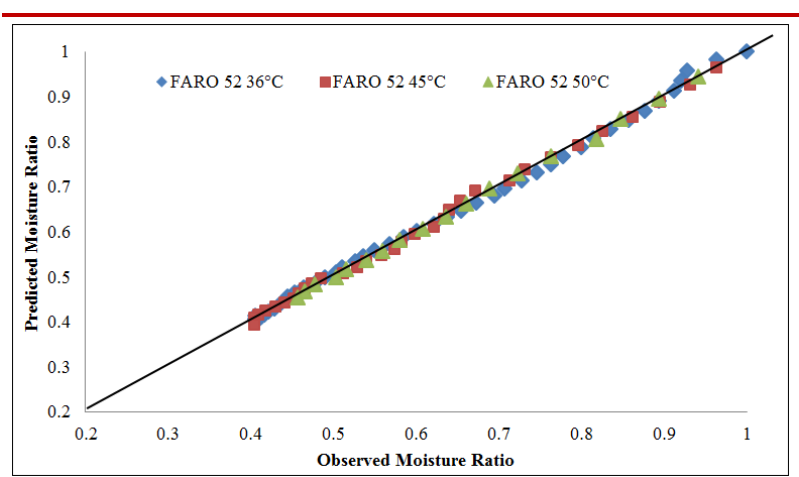

Fig-12: Predicted Moisture Ratio against Observed Moisture Ratio of FARO 52 dried at different temperatures

\section{CONCLUSION}

From the results of this study, it was concluded that, for the rice varieties, the initial moisture content of FARO 52 was higher than FARO 44, the drying time and dynamic EMC decreased as the temperature increased, while the drying rate increased with temperature. The constant rate phase occurred without the period of induction over a temperature range of 36$50^{\circ} \mathrm{C}$, prior to the occurrence of the falling rate phase, while drying at $50^{\circ} \mathrm{C}$ occurred entirely in the falling rate phase. The critical moisture content was observed when drying the rice within a temperature range of $36-50^{\circ} \mathrm{C}$ and increased with the temperature. The effect of the drying temperature on the drying model constants has shown that drying of rice was more appropriate at high temperature of $50^{\circ} \mathrm{C}$. All the seven models were acceptable for predicting the drying behaviour of the rice varieties (with randomized residual plots), only three of the seven models evaluated, namely, the Agbashlo et al., Modified Henderson and Pabis and the Newton models (with patterned residual plots at drying temperatures of $45^{\circ} \mathrm{C}$ and $50^{\circ} \mathrm{C}$ ), were unacceptable for predicting the drying behavior of the rice varieties in the dryer. Of the remaining four models that were acceptable (with randomized residual plots), the Two term model used in this study consistently gave better prediction results with the highest value of $R^{2}$ and the lowest standard error of estimate among the models.

\section{ACKNOWLEDGEMENT}

The financial fellowship support of the University of Maiduguri is gratefully acknowledged. The authors wish to acknowledge the efforts of the laboratory staff of the Department of Food Science and Technology and that of Agricultural and Environmental Resources Engineering, University of Maiduguri, Nigeria with respect to drying runs.

\section{REFERENCES}

1. Nkama, I., Kassum, L. A., \& Jato, A. K. (2011). Rice processing in Nigeria. Intellectual Property and Technology Transfer Office. Ibadan, Nigeria.

2. FAO. (2018). RICE Market Monitor / April 2018 Volume Xxi Issue No. 1 April 2018.
3. Pillaiyar, P., \& Mohandas, R. (1981). Hardness and color in parboiled rice produced at low and high temperature. Journal of Food Science and Technology, 18: 7-9.

4. Juliano, B. O., \& Bechtel, D. (1985). The Rice Grain and Its Gross Composition. In "Rice Chemistry and Technology", ed. By Juliano, B. O. American Association of Cereal Chemists, Inc., St. Paul, Minnesota, 17-37.

5. Bhattacharya, K. R. (2004). Parboiling of rice. In "rice chemistry and technology", E.T. Champagne (ed.), St. Paul, Minn. AACC Int. 329-404.

6. Arslan, N., \& Togrul, H. (2005). Modelling of water sorption isotherms of macaroni stored in a chamber under controlled humidity and thermodynamic approach, Journal of Food Engineering, 69(2): 133-145.

7. Ihekoronye, A. O. (1999). Manual on Small Scale Food Processing A guide to opportunities in Small-Scale Food Processing. The Academic Publishers, Nigeria.

8. Aviara, N. A., \& Igbeka, J. C. (2016). Modeling for Drying of Thin Layer of Native Cassava Starch in Tray Dryer. Journal of Bio-systems Engineering, 41, www.jbeng.org

9. Kajuna, S. T. A. R., Silayo, V. C. K., Mkenda, A., \& Makungu, P. J. J. (2001). Thin-layer drying of diced cassava roots. African Journal of Science and Technology, 2(2):94-100.

10. Akpinar, E. K., Bicer, Y., \& Cetinkaya, F. (2006). Modeling of thin layer drying of parsley leaves in a convective dryer and under open sun. Journal of Food Engineering, 75(3): 308-315.

11. Gunhan, T., Demir, V., Hancioglu E., \& Hepbasli, A. (2005). Mathematical modeling of drying of bay leaves. Energy Conversion and Management. 46: 1667-1679.

12. Midilli, A., \& Kucuk, H. (2003). Mathematical modeling of thin layer drying of pistachio by using solar energy. Energy Conversion and Management, 44:1111-1122.

13. Togrul, Y. T., \& Pehlvan, D. (2004). Modelling of thin layer drying kinetics of some fruit under open air sun drying process. Journal of Food Engineering. 65 (3):413.

14. Yaldiz, O., \& Ertekin, C. (2001). Thin layer solar drying of some vegetables. Drying Technology, 19: 583-596.

15. Doymaz, I. (2005). Drying characteristics and kinetics of okra.Journal of Food Engineering, 69: 275-279.

16. Ozbek, B., \& Danladi, G. (2007). Thin-layer drying characteristics and modeling of mint leaves undergoing microwave treatment. Journal of Food Engineering. 83(4):541-549.

17. Basunia, M. A., \& Abe, T. (1999). Moisture adsorption isotherms of rough rice. Journal Food Engineering, 42:235-242. 
Amina I. Maijalo et al; Saudi J Eng Technol, Dec, 2020; 5(12): 491-500

18. Basunia, M. A., \& Abe, T. (2001). Moisture desorption isotherms of medium grain rough rice. Journal of Stored Product Res, 37: 205-219.

19. Aghbashlo, M., Kianmehr, M. H., \& Arabhosseini, A. (2009). Modeling of thin-layer drying of potato slices in length of continuous band dryer. Energy Conversion and Management, 50:1348-1355.

20. Akpinar, E. K., Bicer, Y., \& Midilli, A. (2003). Modeling and experimental study on drying of apple slices in a convective cyclone dryer. Journal of Food Processing Engineering. 26: 515-541

21. Berbert, P. A., Quaeroz, D. M., Silva, J. S., \& Pinheiro Filho, J. B. (1995). Simulation of coffee drying in fixed bed with periodic airflow reversal. Journal of Agricultural Engineering Research, London, 60(3):167-173.

22. Karathanos, V. T., \& Belessiotis, V. G. (1999). Application of a thin layer equation to drying data of fresh and semi-dried fruits. Journal of Agricultural Engineering Research 74:355-361.

23. Yaldiz, O., Ertekin, C., \& Uzun, H. I. (2001). Mathematical modeling of thin layer solar drying of Sultana grapes. Energy, 26:457-465.

24. Midilli, A., Kucuk, H., \& Yapar, Z. (2002). A new model for single-layer drying. Drying Technology, 20(7):1503-1513
25. Wang, C. Y., \& Singh R. P. (1978). A single layer drying equation for rough rice, ASAE Paper No. 3001, St. Joseph, MI.

26. Sun, D. W., \& Woods J. L. (1994). The selection of sorption isotherm equations for wheat based on the fitting of available data. Journal of Stored Products Research, 30: 27-47.

27. Ojediran, J. O., \& Raji A. O. (2011). Thin-layer drying characteristics of castor (Ricinus communis) seeds. Journal of Food Processing and Preservation, 35: 647-655.

28. Abano, E. E., \& Sam-Amoah, L. L. (2011). Effect of different pretreatments on drying characteristics of banana slice. Journal of Engineering and Applied Science. 6(3):121-129

29. Tunde-Akintunde, T. Y., Afolabi, T. J., \& Akintunde, B. O. (2005). Influence of drying methods on drying of bell- pepper (Capsicum annuum). Journal of Food Engineering. 68 (4):439-442.

30. Hakan, Y. (2016). Investigation of Drying Characteristics of Parboiled Wheat Kernel in a Halogen Lamp Dryer and Its Modelling. International Journal of Pure Applied Science. 2(1):34-39. 